\title{
Color modification and homogenization of sugi wood (Cryptomeria japonica) by steaming
}

\author{
LASZLO TOLVAJ ${ }^{1, \vartheta}$, ENDRE A. BANADICS ${ }^{1, v v}$, SATORU TSUCHIKAWA ${ }^{2, v v v, ~}$ KATSUYA MITSUI $^{3, v v v \vee}$, \\ EDINA PREKLET ${ }^{1, \text { rurv }}$ \\ ${ }^{1}$ Institute of Physics and Electrotechnics, University of Sopron. HU-9400 Sopron, Hungary. Tel + $36-99-518140$,

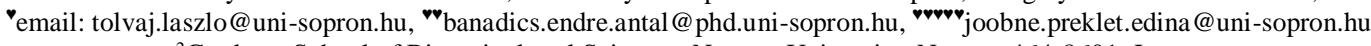 \\ ${ }^{2}$ Graduate School of Bioagricultural Sciences, Nagoya University, Nagoya 464-8601, Japan. \\ rvvemail: st3842@agr.nagoya-u.ac.jp \\ ${ }^{3}$ Gifu Prefectural Human Life Technology Research Institute, Yamada, Takayama 506-0058, Japan \\ vrv»email: mitsui-katsuya@pref.gifu.lg.jp
}

Manuscript received: 8 April 2019. Revision accepted: 25 April 2019.

\begin{abstract}
Tolvaj L, Banadics EA, Tsuchikawa S, Mitsui K, Preklet E. 2019. Color modification and homogenization of sugi wood (Cryptomeria japonica) by steaming. Asian J For 3: 20-24. Color modification and homogenization in wood by steaming is common technique to improve wood attractiveness, yet for some species, the knowledge on such treatment is lacking. This study aimed to investigate the effects of steaming on colors creation and homogenization on sugi (Cryptomeria japonica D. Don) wood. Sugi wood samples were steamed applying broad range of steaming time (0-20 days) at 90 and $110^{\circ} \mathrm{C}$ steaming temperatures. The color change was monitored objectively using the CIE Lab color system. A wide range of colors was created by steaming between the initial color and light brown color depending on the steaming time and temperature. The initial color of earlywood and latewood within sapwood and heartwood covered a wide range of hues. The initial redness and yellowness values ranged from 4.3 to 17.3 and 21.4 to 31.6 units, respectively. Steaming produced excellent color homogenization and increased saturation. After 9 days of steaming at $110^{\circ} \mathrm{C}$, redness values converged, falling between 11.6 and 12.7 units. The yellowness values increased and also converged. After 9 days of steaming at $110^{\circ} \mathrm{C}$ the yellowness values were between 31.6 and 33.5 units. The color saturation of the examined tissues increased considerably and was also showed homogenized. After 9 days of steaming at $110^{\circ} \mathrm{C}$, the saturation values were between 34.1 and 35.6 units (the initial values were between 22.6 and 32.1). It was difficult to differentiate the sapwood and heartwood at the end of the steaming process at $110^{\circ} \mathrm{C}$.
\end{abstract}

Keywords: Color homogenization, color modification, color saturation, steaming, sugi wood

\section{INTRODUCTION}

Various types of timber utilization require different wood characteristics since not all properties of wood suit a particular purpose. Yet, in many cases, unfavorable properties can be improved by modification of the wood material. In terms of appearance, not all wood species have attractive colors. For example, the hue of wood between red and yellow gives us a feeling of warmness. Some species exhibit a white-greyish color without a marked texture, while some other species have disturbingly inhomogeneous coloring.

As technology developed, the disadvantages of unfavorable color in wood can be modified by steaming. The industrial application of steam treatment to change the color of wood started in the second half of the last century with the most frequently steamed species were Beech and black locust. The development in wood-coloring technology was largely supported by scientific research in which systematic efforts to discover the specific effects of steaming treatments for individual wood species started 30 years ago.

Up till now, the steaming behavior of black locusts has the most detailed literature. Some of the most relevant publications concerning the steaming behavior of black locusts were Tolvaj and Faix (1996); Molnar (1998); Tolvaj et al. (2010); Dzurenda (2018a). Based on these studies, the unattractive and highly inhomogeneous greenish-yellow color of black locust could be modified to resemble a chocolate brown color. Fewer studies are available concerning the investigation of the steaming behavior of beech than for black locusts (Milic et al. 2015, Geffert et al. 2017). Beech is usually steamed to turn its whitish-grey initial color into a more attractive reddish hue. The color difference between the white and red heartwood of beech can also be minimized by steaming (Tolvaj et al. 2009).

There are fewer publications regarding the steaming properties of species other than beech and black locust. Among such publications, Varga and van der Zee (2008) studied the alteration of some mechanical and physical properties of two European and two tropical hardwood species caused by steaming. Straze and Gorisek (2008) and by Dianiskova et al. (2008) investigated the possible color variations of cherry wood generated by steam treatment. Other studies (e.g., Tolvaj and Molnar 2006, Todaro et al. 2012 a,b, Csanady et al. 2015) found that steaming can reduce the great color difference between sapwood and heartwood of Turkey oak. Recently, Banadics and Tolvaj 
(2019) studied the color change of poplar (Populus $x$ euramericana $c v$. pannonia) by steaming to obtain attractive colors suitable for various indoor applications. Steaming was also found to be a proper technique to turn the naturally unattractive color of poplar wood to a pleasant brown color. The steaming was able to double the color saturation, which is a significant result in terms of industrial application. The treatment increased both redness and yellowness values and reduced the lightness. Dzurenda (2017, 2018b) investigated the steaming behavior of oak and maple wood to get attractive brown color.

It is hard to find results in the literature regarding the color modification of softwoods by steaming. Among the limited literature, Tolvaj et al (2012) did steaming experiment on Scots pine and spruce samples by applying board range of steaming times (0-22 days) and the temperatures between 70 and $100^{\circ} \mathrm{C}$. The result showed that wide ranges of colors were created between the initial and light brown colors. These new colors were similar to those of aged indoor wooden structures and furniture. Another study by Kaygin et al. (2014) investigated surface quality and hardness of eastern red cedar as function of steaming time and temperature.

Until now, there is limited trial to look at the effect of steaming treatment of colorization of sugi (Cryptomeria japonica D. Don) wood. In its raw materials, the color of sugi timber is highly inhomogeneous. Its heartwood is much darker and redder than the sapwood. As such, this study aimed to investigate the effects of steaming on color homogenization of sugi wood and to find all of the possible colors created. The created diagrams are useful for finding the proper steaming treatments if a specific color is required.

\section{MATERIALS AND METHODS}

Sugi (Cryptomeria japonica D. Don) samples were prepared for the steaming tests. The size of each specimen sample was $150 \times 20 \times 10 \mathrm{~mm}$. The largest surface contained only earlywood or latewood (tangential surface). Half part of the specimens was sapwood, and the other half part was heartwood. The average moisture content of the samples was $9.1 \%$ before the steaming process.

All steaming temperatures and steaming times were represented by a series of 10 samples and 10 randomly chosen points were used for color measurement on each sample. The steaming was carried out in a steaming chamber at $100 \%$ relative humidity at 90 and $110^{\circ} \mathrm{C}$. Wood specimens were placed in a large pot with distilled water for conditioning the air to generate $100 \%$ relative humidity. At $110^{\circ} \mathrm{C}$ the pot was able to maintain the pressure. The pots were heated in a drying chamber to the indicated temperatures. The steaming process started with four hours of heating. The temperature was regulated automatically around the preset values with a tolerance of $0.5^{\circ} \mathrm{C}$. Specimens were removed after 2, 5, 9, 14 and 20 days of steaming, respectively. The wood specimens were conditioned for one month both before and after steaming at room temperature before the color measurements (laboratory condition).

The color of the wood specimens was measured before and after steaming. Measurements were carried out with a colorimeter (Konica-Minolta 2600d) on the tangential surface. The color values of earlywood and latewood were determined separately. The CIE-Lab color measurement system was applied, and 10 randomly chosen dots were measured on each sample. The $\mathrm{L}^{*}, \mathrm{a}^{*}, \mathrm{~b}^{*}$ color coordinates were calculated based on the $\mathrm{D}_{65}$ illuminant and $10^{\circ}$ standard observer with a test-window diameter of $3 \mathrm{~mm}$.

\section{RESULTS AND DISCUSSION}

The tissues of sugi (Cryptomeria japonica) have highly varying color hue and lightness characteristics. The initial average color data of the investigated samples are presented in Table 1.

Heartwood was much darker than sapwood. Earlywood in sapwood, especially, was much lighter than in all other tissues. Latewood in sapwood had the same lightness as did earlywood in heartwood. The darkest tissue was the latewood in heartwood. The border between the dark and light portions was usually sharp.

The redness of sugi wood showed the greatest diversity among the tissues. Latewood in sapwood and earlywood in heartwood were more than two times redder, and latewood in heartwood three times redder than the earlywood in sapwood. There were moderate differences among the tissues in yellowness. These great color differences can be diminished by steaming. The standard deviation (SD) values were small, showing a high degree of color homogeneity within the earlywood and the latewood, respectively.

Figure 1 presents the redness change caused by steaming at $90^{\circ} \mathrm{C}$. The color dots of all tissues converged with elapsed steaming time, representing color homogenization. The color homogenization continued up to the $14^{\text {th }}$ day of steaming. During this steaming period, the initial redness value difference among the tissues (13 units) was reduced to 2.5 units. The redness of the two types of earlywood was equal after 14 days of steaming, and the same happened for the latewood as well. However, the final values of redness (after 20 days) were different for earlywood and latewood.

Table 1. Initial color data of different tissues of sugi wood (average and standard deviation SD). S=sapwood, $\mathrm{H}=$ heartwood, $\mathrm{E}=$ earlywood, $\mathrm{L}=$ latewood

\begin{tabular}{lcccccc}
\hline & $\mathbf{L}^{*}$ & SD & $\mathbf{a}^{*}$ & SD & $\mathbf{b}^{*}$ & SD \\
\hline SE & 81.07 & 1.93 & 4.99 & 0.90 & 21.80 & 1.11 \\
SL & 71.02 & 2.00 & 11.69 & 1.35 & 30.43 & 2.63 \\
HE & 71.25 & 1.73 & 12.46 & 1.01 & 23.48 & 1.16 \\
HL & 62.20 & 2.09 & 16.45 & 1.37 & 27.42 & 1.84 \\
\hline
\end{tabular}


Steaming at $110^{\circ} \mathrm{C}$ caused similar redness change as steaming at $90^{\circ} \mathrm{C}$, but the redness change was more intense during the first two days of steaming (Figure 2). At this temperature, homogenization was achieved after the first nine days of steaming. The redness difference among the tissues was only 1.2 units after nine days of steaming. This finding suggests that if we want to steam sugi wood for color homogenization, nine days are sufficient to achieve maximum homogenization. From an industry point of view, the proper steaming time is five days for color homogenization. The redness change is negligible after this period of steaming at $110^{\circ} \mathrm{C}$. It is better not to homogenize the color completely. The unique color harmony in wood is produced by moderate color differences between earlywood and latewood. Applying the proper steaming time and temperature, optimal color harmony may be generated.

The redness values were almost constant in most parts of the applied steaming period (between 5 and 20 days). This is a highly important result. It means that the chromophore chemical groups creating redness are stable during the thermal treatment at $110^{\circ} \mathrm{C}$, and even more stable at ambient temperatures during everyday usage. The color shift is related to the alteration of conjugated doublebound chemical systems. These bounds can be found in the lignin and the extractives. Thus, the color changes in the examined temperature range originated mostly from the alteration of the extractives. Previous research showed that flavonoids play a significant role in the discoloration of wood (Csonka-Rákosa 2005).

The steaming results of wood species other than sugi (black locust, beech, Turkey oak) indicated that the red color created by steaming was not stable above $100^{\circ} \mathrm{C}$ (Tolvaj et al. 2009, 2010, Tolvaj and Molnar 2006). The

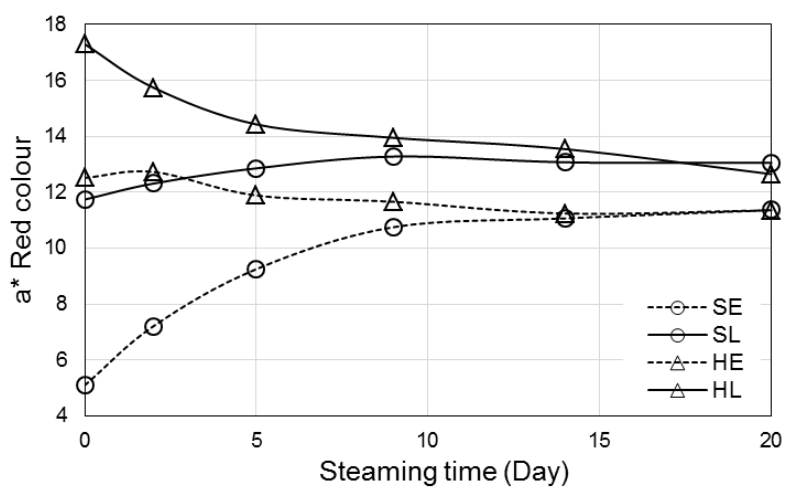

Figure 1. The redness change of different tissues during steaming at $90^{\circ} \mathrm{C}$. ( $\mathrm{S}=$ sapwood, $\mathrm{H}=$ heartwood, $\mathrm{E}=$ earlywood, $\mathrm{L}=$ latewood) high temperature degraded the newly generated chromophore molecules, and the steam leached out part of these colored chemical compounds from the samples, resulting in the decrease of $\mathrm{a}^{*}$ values. In contrast, the experiments showed that the chromophore groups of sugi were stable during the 20 days of steaming at $110^{\circ} \mathrm{C}$. The color stability for sugi wood is an important advantage when steaming.

Figure 3 presents the yellowness change caused by steaming at $90^{\circ} \mathrm{C}$. The color dots of all tissues converged, representing color homogenization. The color homogenization continued up to the $14^{\text {th }}$ day of steaming. During this steaming period, the initial yellowness value difference (9 units) was reduced to 3.1 units. In contrast to redness, the yellowness of the two types of tissues of sapwood was almost equal after 14 days of steaming, and the same happened for the heartwood as well. However, the end values (after 20 days) were different for sapwood and heartwood.

The yellowness change at $110^{\circ} \mathrm{C}$ was different from the change at $90^{\circ} \mathrm{C}$ (Figure 4). Most of the yellowness change happened during the first two days of steaming. The yellowness of sapwood hardly changed after this period and the yellowness value of heartwood slightly increased during the further steaming process. The average yellowness end value at $110^{\circ} \mathrm{C}$ (33.5 units) was much higher than at $90^{\circ} \mathrm{C}$ (27.3units).

The lightness difference among the tissues was 18 units at the beginning of steaming (Figure 5). The lightness values decreased continuously with elapsed steaming time at both temperatures. The difference between the effects of the two temperatures was only that the $90^{\circ} \mathrm{C}$ temperature resulted in smaller (6 units) lightness homogenization than the $110^{\circ} \mathrm{C}$ (11 units).

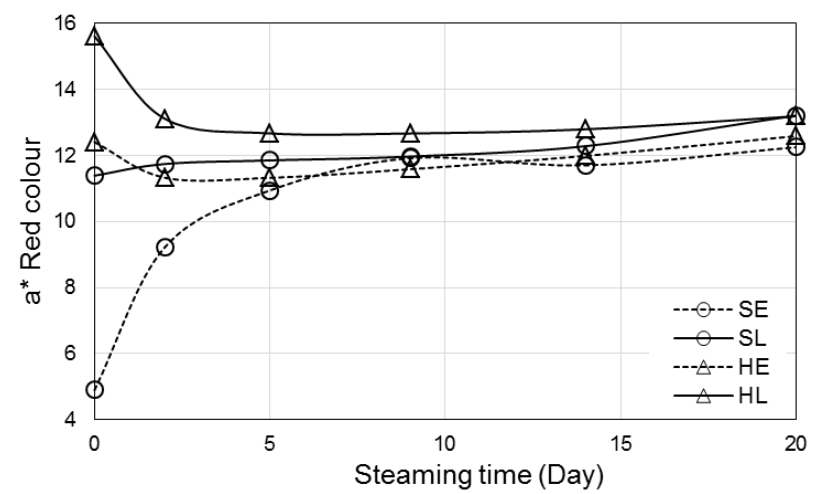

Figure 2. The redness change of different tissues during steaming at $110^{\circ} \mathrm{C} . \quad(\mathrm{S}=$ sapwood, $\mathrm{H}=$ heartwood, $\mathrm{E}=$ earlywood, $\mathrm{L}=$ latewood) 


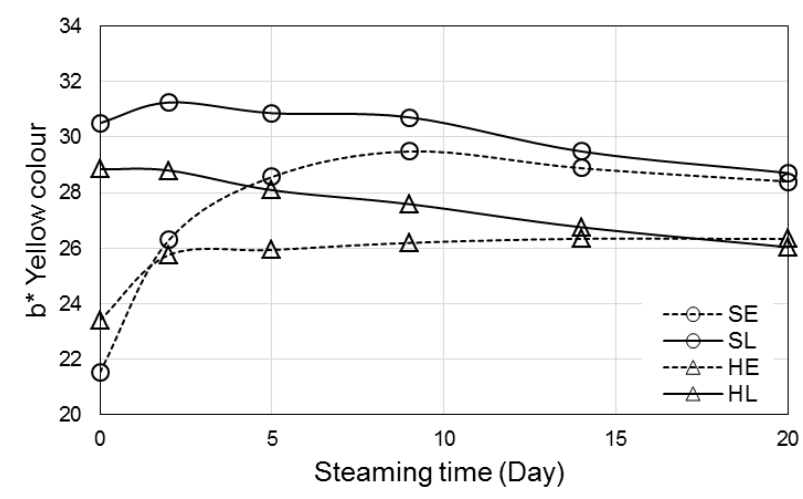

Figure 3. The yellowness change of different tissues during steaming at $90^{\circ} \mathrm{C}$. ( $\mathrm{S}=$ sapwood, $\mathrm{H}=$ heartwood, $\mathrm{E}=$ =arlywood, L=latewood)

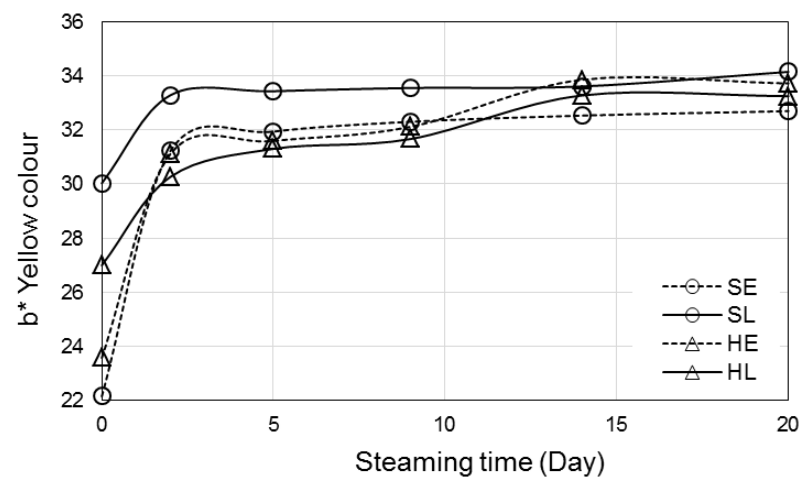

Figure 4. The yellowness change of different tissues during steaming at $110^{\circ} \mathrm{C}$. ( $\mathrm{S}=$ sapwood, $\mathrm{H}=$ heartwood, $\mathrm{E}=$ =arlywood, $\mathrm{L}=$ latewood)

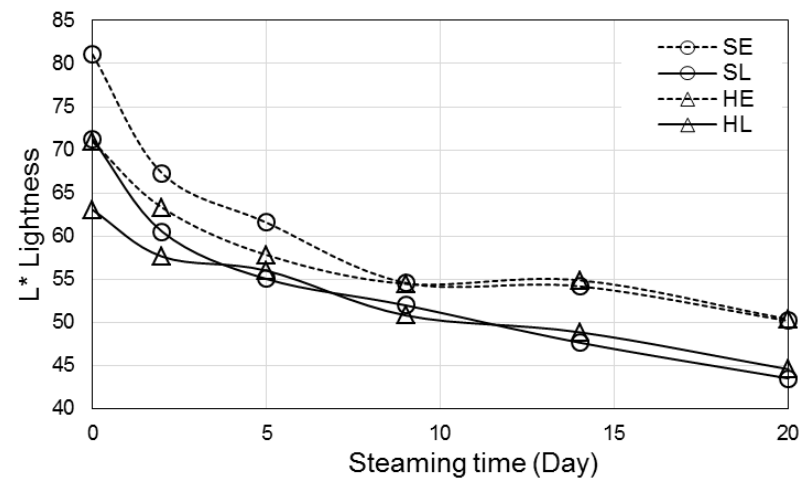

Figure 5. The lightness change of different tissues during steaming at $110^{\circ} \mathrm{C}$. ( $\mathrm{S}=$ sapwood, $\mathrm{H}=$ heartwood, $\mathrm{E}=$ =earlywood, L=latewood)

The homogenization effect of steaming can be visualized by plotting the color dots on the $a^{*}-b^{*}$ plane. Figures 6 and 7 show the colors generated by steaming at $90^{\circ} \mathrm{C}$ and $110^{\circ} \mathrm{C}$, respectively (Filled marks represent the color dots of samples before steaming). The initial color dots are evidently far from each other. The color dots

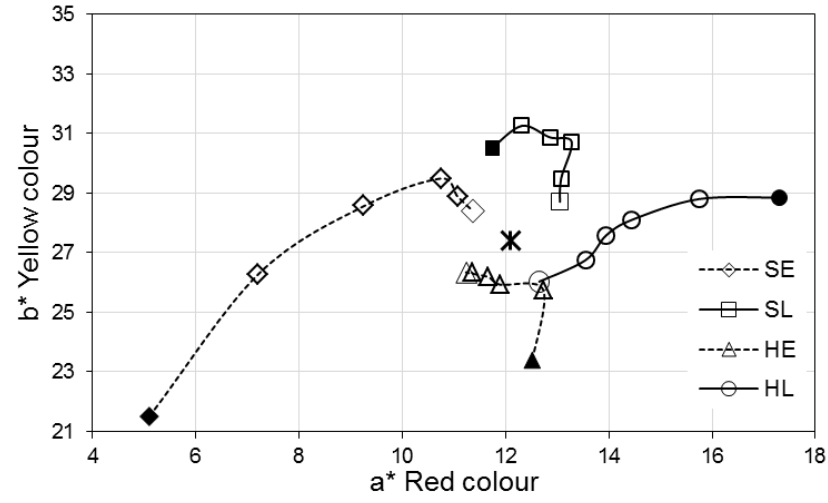

Figure 6. The color dots' locations on the $\mathrm{b}^{*}-\mathrm{a}^{*}$ plane during steaming at $90^{\circ} \mathrm{C}$. (Filled marks mean unsteamed)

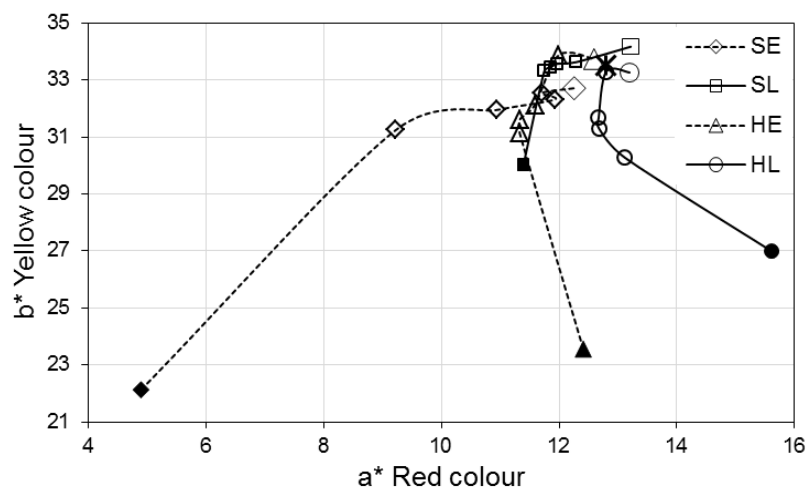

Figure 7. The color dots' locations on the $\mathrm{b}^{*}-\mathrm{a}^{*}$ plane during steaming at $110^{\circ} \mathrm{C}$. (Filled marks mean unsteamed)

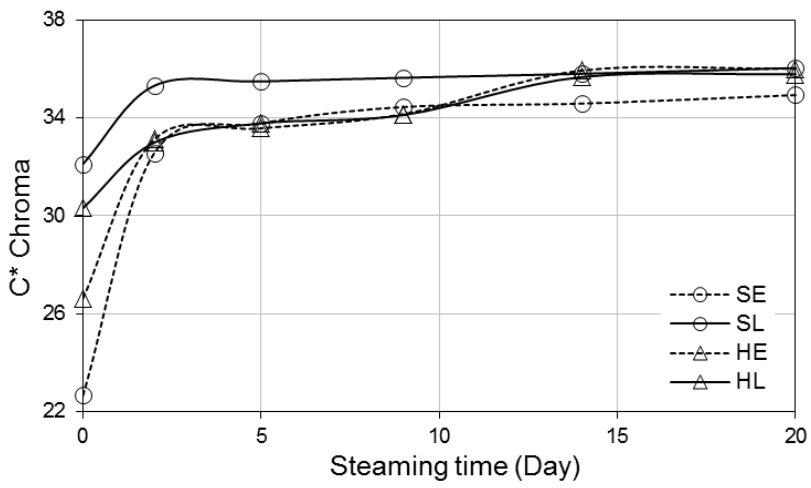

Figure 8. The change of color saturation for different tissues during steaming at $110^{\circ} \mathrm{C} . \quad(\mathrm{S}=$ sapwood, $\mathrm{H}=$ heartwood, $\mathrm{E}=$ earlywood, L=latewood)

converge during the steaming process, towards a center dot. The coordinates of this center dot were; $\mathrm{a}^{*}=12.1$ and $b^{*}=27.4$ units. The distances among the dots decreased representing the homogenization.

Similar changes were visible when sugi wood was steamed at $110^{\circ} \mathrm{C}$ (Figure 7). The changes were large 
during the first two days of steaming. The direction of changes differed compared to the effect of steaming at $90^{\circ} \mathrm{C}$. The color dots moved towards a common point, but this point was not in a central position. This happened because the redness values increased considerably, elevating the color dots on the chart during the steaming. The middle point of the final color dots is located on the top of the diagram; its coordinates are $\mathrm{a}^{*}=12.8$ and $\mathrm{b}^{*}=$ 33.5 units. The color dots were close to each other after the $5^{\text {th }}$ day of steaming, representing color homogenization.

The chroma is also an important parameter because it represents the saturation of the given color. High saturation means that the color is vivid. Low saturation represents a dull color. The values of chroma hardly changed during steaming at $90^{\circ} \mathrm{C}$. The only exception was the earlywood part in sapwood. Its chroma increased continuously during the first nine days of steaming and remained constant after that. All tissues became more saturated in color during the steaming at $110^{\circ} \mathrm{C}$ (Figure 8). Most of change happened within the first two hours of steaming. The chroma of earlywood increased much more than the chroma of latewood in sapwood as well as heartwood. The chroma hardly changed after the second day of steaming. Only the tissues of heartwood showed some increase in chroma after the second day of steaming. This result is important for the wood industry, because a more saturated color is generally more acceptable for humans than a dull color.

In conclusion, the color of sugi wood is highly inhomogeneous. It has light earlywood in sapwood. The color of latewood in sapwood has similar color to the earlywood in heartwood. This color is darker and much redder than the color of earlywood in sapwood. The latewood in heartwood has the darkest and most reddish color. Steaming was able to reduce these large color differences. A wide range of colors was created by steaming between the initial color and brown color depending on the steaming time and temperature. The color homogenization was so successful that it was difficult to differentiate between the sapwood and the heartwood by naked eye at the end of the steaming process. The effective steaming time for color homogenization was nine and two days at $90^{\circ} \mathrm{C}$ and $110^{\circ} \mathrm{C}$, respectively. The chroma of all tissues increased considerably by steaming at $110^{\circ} \mathrm{C}$, showing that steaming generated saturated color. The color data of steamed sugi wood are useful to find out the appropriate steaming parameters for achieving a specific color and color harmony.

\section{ACKNOWLEDGEMENTS}

This research was sponsored by the TÉT-16-1-20160186, "Development of extractive-transport based hydrothermal treatment technology for the color modification and homogenization of selected Hungarian and Japanese wood species" project. The financial support is gratefully acknowledged.

\section{REFERENCES}

Banadics EA, Tolvaj L. 2019. Colour modification of poplar wood by steaming for brown colour. Eur J Wood, Wood Prod DOI: 10.1007/s00107-019-01397-9

Csanady E, Magoss E, Tolvaj L. 2015. Quality of Machined Wood Surfaces. Springer, Berlin.

Csonkáné, Rákosa R. 2005. A flavonoidok szerepe a faanyag hőhatás okozta átalakulásaiban. Faipar 53 (2): 23-27. [in Hungarian with English abstract]

Dianisková M, Babiak M, Tolvaj L. 2008. Colour homogenisation of cherrywood (Cerasus avium L.) and black locust (Robinia pseudoacacia L.) during steaming. Wood Res Slovakia 53 (4): 45-58.

Dzurenda L. 2017. Modification of wood colour of Acer platanoides L. to a brown-red shade caused by thermal treatment For Wood Technol 98: 26-32.

Dzurenda L. 2018a. Colour modification of Robinia pseudoacacia L. during the processes of heat treatment with saturated water steam. Acta Facultatis Xylologiae Zvolen 60 (1): 61-70. DOI: 10.17423/afx.2018.60.1.07

Dzurenda L. 2018b. The Shades of Color of Quercus robur L. Wood Obtained through the Processes of Thermal Treatment with Saturated Water Vapour. BioRes 13 (1): 1525-1533.

Geffert A, Vybohová E, Geffertová J. 2017. Characterization of the changes of colour and some wood components on the surface of steamed beech wood. Acta Facultatis Xylologiae Zvolen 59 (1): 49-57. DOI: 10.17423/afx.2017.59.1.05

Kaygin B, Koc KH, Hiziroglu S. 2014. Surface quality and hardness of eastern redcedar as function of steaming. J Wood Sci 60 (4): 243-248. DOI: $10.1007 / \mathrm{s} 10086-014-1399-\mathrm{x}$

Milić G, Todorović N, Popadić R. 2015. Influence of steaming on drying quality and colour of beech timber. Glasnik Šmarskog Fakulteta 83 96. DOI: 10.2298/GSF1512083M

Molnar S. 1998. Die technischen Eigenschaften und hydrothermische Behandlung des Robinienholzes. In: Molnar S (ed.). Die Robinie Rohstoff für die Zukunft, Stiftung für die Holzwissenschaft. Budapest. [Germany]

Straze A, Gorisek Z. 2008. Research on colour variation of steamed Cherry wood (Prunus avium L.). Wood Res Slovakia 52 (2): 77-90.

Todaro L, Zuccaro L, Marra M, Basso B, Scopa A. 2012a. Steaming effects on selected wood properties of Turkey oak by spectral analysis. Wood Sci Technol 46 (1-3): 89-100. DOI: 10.1007/s00226010-0377-8

Todaro L, Zanuttini R, Scopa A, Moretti N. 2012b. Influence of combined hydro-thermal treatments on selected properties of Turkey oak (Quercus cerris L.) wood. Wood Sci Technol 46 (1-3): 563-578. DOI: 10.1007/s00226-011-0430-2

Tolvaj L, Faix O. 1996. Modification of wood colour by steaming. ICWSF '96 Conference, Sopron, 10-12 April 1996. [Hungary].

Tolvaj L, Molnár S. 2006. Colour homogenisation of hardwood species by steaming. Acta Silvatica et Lignaria Hungarica 2: 105-112.

Tolvaj L, Nemeth R, Varga D, Molnar S. 2009. Colour homogenisation of beech wood by steam treatment. Drewno-Wood 52: 5-17.

Tolvaj L, Molnár S, Németh R, Varga D. 2010. Colour modification of black locust depending on the steaming parameters. Wood Res Slovakia 55 (2): 81-88.

Tolvaj L, Papp G, Varga D, Lang E. 2012. Effect of steaming on the colour change of softwoods. BioRes 7 (3): 2799-2808.

Varga D, Van der Zee ME. 2008. Influence of steaming on selected wood properties of four hardwood species. Holz Roh Werkstoff 66 (1): 11 18. DOI: 10.1007/s00107-007-0205-5 